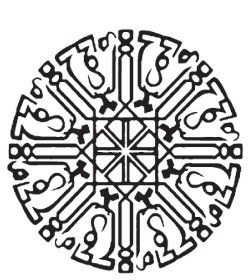

\title{
Menakar Progresivitas Hukum Wakaf dalam Pengembanganwakaf Uang di Indonesia
}

\author{
Mansur Efendi \\ IAIN Surakarta \\ mansur.iainsolo@gmail.com
}

\begin{abstract}
This study explained the progressivity of waqf law in Indonesia, especially cash waqf development. The progressivity of waqf law is good enough to respond to global challenges or field needs. The progressivity of waqf law in Indonesia can be observed from the development of waqf's act regulations from pre-independence era until the postreformation era. In cash waqf, there is fundamental law progressivity. It marked by act No. 44 year 2004 about waqf. Those act described new paradigm must be built on waqf management in Indonesia. Furthermore, those act also gave a space for cash waqf as a part of waqf development in Indonesia. Another progressivity which appeared in those act is waqf treasure object. Act No. 44 year 2004 confirmed that waqf treasure object is not only immovable object, as public understanding, but also applied on the movable object. Furthermore, the progressivity of waqf law has reached on waqf management and its institutional aspect. At least, this progressivity described collective awareness on the strategic role of waqf in Indonesia's economics.
\end{abstract}

Keywords: progressivity, waqf law, cash waqf

\begin{abstract}
Abstrak
Tulisan ini mengulasseputar progresivitas hukum wakaf di Indonesia, terutama yang berkaitan dengan pengembangan wakaf uang (cash waqf). Progres hukum wakaf di Indonesia sudah cukup baik dalam menjawab tantangan global maupun menjawab kebutuhan lapangan. Progresivitas hukum wakaf di Indonesia bisa dicermati dari perkembangan peraturan perundangan wakaf sejak masa sebelum kemerdekaan sampai dengan masa setelah reformasi. Mengenai wakaf uang sendiri, terdapat progresivitas hukum yang fundamental. Hal ini ditandai dengan lahirnya Undang-Undang Nomor 41 Tahun 2004 tentang Wakaf. Undang-undang tersebut menggambarkan paradigma baru yang harus dibangun dalam tata kelola wakaf di Indonesia. lebih jauh, Undang-undang tersebut juga memberikan ruang bagi pengelolaan wakaf uang sebagai bagian dari pengembangan wakaf di Indonesia. Kemajuan
\end{abstract}


lain yang nampak dalam Undang-undang tersebut adalah mengenai obyek harta wakaf. UU No. 41 Tahun 2004 menegaskan bahwa obyek harta wakaf tidak hanya berupa harta yang tidak bergerak sebagaimana yang dipahami oleh publik, melainkan juga berlaku untuk harta yang bergerak. Lebih jauh, progresivitas hukum wakaf juga sudah sampai pada tata kelola wakaf uang dan aspek kelembagaannya. Progresivitas ini setidaknya menggambarkan kesadaran kolektif akan peran strategis wakaf dalam perekonomian di Indonesia.

Kata Kunci: progresivitas, hukum wakaf, wakaf uang

\section{A. Pendahuluan}

Potensi wakaf di Indonesia menjadi peluang sekaligus tantangan dalam mewujudkan tujuan suci dari wakaf itu sendiri. Potensi wakaf yang berupa tanah wakaf di Indonesia mencapai 2.686.536.656,68 meter persegi (dua milyar enam ratus delapan puluh enam juta lima ratus tiga puluh enam ribu enam ratus lima puluh enam koma enam puluh delapan meter persegi) atau 268.653,67 hektar (dua ratus enam puluh delapan ribu enam ratus lima puluh tiga koma enam tujuh hektar). Tanah wakaf tersebut tersebar di 366.595 lokasi di seluruh Indonesia (Badan Wakaf Indonesia 2008a).

Potensi tanah wakaf yang cukup besar ini belum berbanding lurus dengan manfaat yang dihasilkan. Penggunaan tanah wakaf baru sekedar untuk kegiatan sosial dan keagamaan. Hasil penelitian Pusat Bahasa dan Budaya (PBB) UIN Syarif Hidayatullah Jakarta, tahun 2006, menunjukkan bahwa harta wakaf lebih banyak bersifat diam (77\%) daripada yang menghasilkan atau produktif (23\%)(Badan Wakaf Indonesia 2008b). Padahal apabila potensi tanah wakaf dikelola untuk sektor produktif, maka akan menghasilkan nilai tambah (added value) yang signifikan.

Pelaksanaan wakaf produktif di Indonesia sendiri sudah dimulai, namun demikian jumlahnya masih cenderung sedikit. Masih banyak kendala yang dihadapi sehingga pelaksanaan wakaf produktif belum optimal. Peruntukan wakaf masih banyak didominasi untuk peribadatan, seperti masjid, langgar dan surau. Sementara peruntukan harta wakaf di sektor produktif jumlahnya masih sedikit. Banyak faktor yang mempengaruhi kondisi ini, salah satunya adalah paradigma wakaf yang identik dengan harta tidak bergerak (tanah). Padahal potensi wakaf dari harta yang bergerak (uang), akan mempercepat hasil guna dan daya guna pengelolaan wakaf.

Kuatnya paradigma harta wakaf yang identik dengan tanah tersebut, memiliki relasi dengan perkembangan hukum wakaf di Indonesia. Sejak masa sebelum kemerdekaan sampai sebelum reformasi, peraturan perundangan wakaf masih berorientasi pada pengelolaan harta wakaf yang berupa benda tidak bergerak.Baru pada masa reformasi, wacana wakaf uang menguat di ruang publik. Penguatan wacana ini tidak lepas dari perkembangan wakaf uang di beberapa negara yang lain.

al-aḥ̂ām vol. 3, Nomor 2, 2018 


\section{B. Pengertian Wakaf}

Kata "Wakaf" atau "Waqf" berasal dari bahasa Arab "Waqafa". Asal kata "Waqafa" berarti "menahan" atau "berhenti" atau "diam di tempat" atau tetap berdiri". Kata "WaqafaYuqifu-Waqfan" sama artinya dengan "HabasaYahbisu-Tahbisan"(Zuhaili 1985).

Secara terminologi, kalangan ulama Syafi'iyah mendefinisikan bahwa wakaf adalah menahan harta yang dapat memberikan manfaat dan tetap materi bendanya ( $a l$-'ain) dengan memutuskan hak pengelolaan dari wakif kepada nazhir sesuai ketentuan syariah (Anshori 2005). Berbeda dengan ulama Syafi'iyah, ulama Hanafiyah berpendapat bahwa wakaf hanya terjadi pada manfaat dari harta, bukan pada aset hartanya. Sehingga, kepemilikan harta wakaf masih menjadi milik wakif. Dengan demikian, bila wakif menginginkan kembali wakafnya, maka hal ini diperbolehkan (Zuhaili 1985).

Sedangkan menurut ulama Malikiyah, wakaf didefinisikan dengan memberikan manfaat dari harta yang dimiliki seseorang untuk diberikan kepada orang lain yang berhak dalam waktu yang ditentukan wakif pada saat akad wakaf. Sementara ulama Hanabilah mengartikan wakaf sebagai menahan asal da memberikan hasilnya.secara terminologi, kalangan ulama Syafi'iyah mendefinisikan bahwa wakaf adalah menahan harta yang dapat memberikan manfaat dan tetap materi bendanya (al-'ain) dengan memutuskan hak pengelolaan dari wakif kepada nazhir sesuai ketentuan syariah (Anshori 2005). Berbeda dengan ulama Syafi'iyah, ulama Hanafiyah berpendapat bahwa wakaf hanya terjadi pada manfaat dari harta, bukan pada aset hartanya. Sehingga, kepemilikan harta wakaf masih menjadi milik wakif. Dengan demikian, bila wakif menginginkan kembali wakafnya, maka hal ini diperbolehkan (Zuhaili 1985). Sedangkan menurut ulama Malikiyah, wakaf didefinisikan dengan memberikan manfaat dari harta yang dimiliki seseorang untuk diberikan kepada orang lain yang berhak dalam waktu yang ditentukan wakif pada saat akad wakaf. Sementara ulama Hanabilah mengartikan wakaf sebagai menahan asal dan memberikan hasilnya.

Sedangkan pengertian wakaf dalam Undang-Undang sebagai berikut :

a) Kompilasi Hukum Islam Pasal 215 ayat 1 menjelaskan bahwa wakaf adalah perbuatan hukum seseorang atau kelompok orang atau badan hukum yang memisahkan sebagian dari benda miliknya dan melembagakannya untuk selama-lamanya guna kepentingan ibadat atau keperluan umum lainnya sesuai dengan ajaran islam Berdasarkan ketentuan Pasal 215 ayat $4 \mathrm{KHI}$ tentang pengertian benda wakaf adalah : Segala benda baik bergerak atau tidak bergerak yang memiliki daya tahan yang tidak hanya sekali pakai dan bernilai menurut ajaran Islam.

b) Menurut UU No. 41 Tahun 2004 Tentang Wakaf Pasal 1 ayat (1) menyatakan bahwa wakaf adalah perbuatan hukum wakif untuk memisahkan dan/atau menyerahkan sebagian harta benda miliknya untuk dimanfaatkan selamanya atau untuk jangka waktu 
tertentu sesuai dengan kepentingannya guna keperluan ibadah dan/atau kesejahteraan umum menurut Syari'ah.

c) Menurut PP No. 42 Tahun 2006 Tentang Pelaksanaan UU No. 41 Tahun 2004 tentang wakaf Pasal 1 ayat (1) menyatakan wakaf adalah perbuatan hukum wakif untuk memisahkan dan/atau menyerahkan sebagian harta benda miliknya untuk dimanfaatkan selamanya atau untuk jangka waktu tertentu sesuai dengan kepentingannya guna keperluan ibadah dan/atau kesejahteraan umum menurut Syari'ah.

\section{Keunggulan Wakaf Uang}

Dibandingkan dengan wakaf benda tidak bergerak, wakaf uang memiliki kelebihan. Kelebihan wakaf uang antara lain besarnya nilai nominal wakaf uang bisa variatif. Dengan nilai nominal yang variatif, maka wakaf uang relatif lebih terjangkau oleh semua kalangan. Hal ini berbeda dengan wakaf tanah yang cenderung hanya bisa dijangkau oleh segmen masyarakat tertentu. Wakaf uang yang memiliki peluang jangkauan luas, diharapkan tingkat penghimpunannya juga akan lebih optimal.

Keunggulan wakaf uang yang lain adalah pada aspek penggunaannya. Penggunaan wakaf uang akan cenderung kaya alternatif.Fleksibilitas penggunaan wakaf uang sangat tepat untuk penciptaan bisnis investasi, dengan sektor yang beragam. Hasil pemanfaatan wakaf uang tersebut, dapat dimanfaatkan pada bidang keagamaan, pendidikan, dan pelayanan sosial. Wakaf jenis ini lebih bernilai benefit daripada wakaf benda tak bergerak, seperti tanah.

Berangkat dari kelebihan wakaf uang tersebut, beberapa negara sudah menerapkan untuk meningkatkan produktivitas wakaf, misalnya adalah Singapura. Pengelolaan harta wakaf di Singapura dilakukan dengan model yang inovatif dan profesional. Aset-aset wakaf dibiayai melalui patungan antara Baitul Mal yang dikelola MUIS dan pembiayaan internal dari nazhir. Selain itu, aset wakaf juga dibiayai melalui peluncuran sukuk atau obligasi syariah di pasar modal dengan akad musyarakah atau bagi hasil yang diberi nama "Musharakah Bond". Aset-aset wakaf di Singapura tidak hanya berupa masjid, namun juga aset produktif. Aset tersebut antara lain Wakaf Jabbar di Duku Road yang berupa kompleks perumahan dengan sewa tahunan mencapai 36.000 dolar Singapura per tahun pada tahun 2005. Selain itu juga properti di daerah Telok Indah, di kawasan ini berdiri masjid, kompleks pertokoan dan 20 unit apartemen. Keuntungan yang dihasilkan oleh aset wakaf produktif tersebut disalurkan ke sektor sosial dan keagamaan (Muljawan, Sukmana, and Yumanita 2016).

Di Malaysia, pengembangan wakaf juga sudah mulai merambah pada harta bergerak, misalnya adalah wakaf saham. Mekanisme saham wakaf ini adalah nazhir menghimpun dana dari masyarakat berupa wakaf uang atau penggantian aset wakaf yang lama dengan saham wakaf, dimana perlembar saham dihargai RM 10. Beberapa proyek yang dibiayai

al-aḥkām vol. 3, Nomor 2, 2018 
dari saham wakaf ini antara lain Bangunan Saham Wakaf Johor, bangunan ini merupakan ruang kantor yang disewakan kepada perusahaan maupun pemerintah. Selain itu juga untuk membiayai proyek wakaf perkebunan kelapa sawit seluas 3.800 hektar. Lebih dari itu, saham wakaf juga digunakan untuk pengadaan asrama pelajar di Mesir. Asrama berlantai enam di daerah Qahirah, Mesir tersebut dibeli pada tahun 2006. Adapun proyek pembeliannya dilakukan dengan pengumpulan dana senilai RM 4.500.000 melalui saham wakaf (Muljawan, Sukmana, and Yumanita 2016).

Pengembangan wakaf di Arab Saudi juga sudah merambah pada bentuk saham, pertokoan serta perhotelan, dan salah satu yang terkenal adalah Zam-zam Tower. Zam-zam Tower adalah menara yang berada di Mekah, tepatnya di sekitar Masjidil Haram. Zam-zam Tower berdiri di atas tanah yang diwakafkan oleh Raja Arab Saudi, di bawah pengelolaan King Abdul Azis Waqf (KAAW) sebagai nazhir. Tanah wakaf tersebut disewakan kepada Binladin Group dengan sistem konsesi yang kemudian disebut sebagai BOT (Buid-Operate-Transfer) dengan jangka waktu hingga 28 tahun. Pembiayaan megaproyek tersebut mencapai US\$ 390.000.000 dengan menerbitkan sukuk Intifa'a dengan jangka waktu 24 tahun. Sukuk Intifa'a sendiri merupakan sejenis sukuk yang memungkinkan pembelinya dapat menyewa ruang yang berada di dalam kompleks Zam-zam Tower selama jangka waktu tertentu (Muljawan, Sukmana, and Yumanita 2016).

\section{Perkembangan Hukum Wakaf di Indonesia}

Perkembangan hukum wakaf di Indoneisa memiliki akar sejarah yang cukup panjang. Bahkan regulasi yang mengatur mengenai wakaf sudah ada sejak jauh sebelum masa penjajahan Belanda di Indonesia. Pada masa tersebut, tata kelola wakaf telah diatur melalui hukum adat yang tidak tertulis dan menjadikan nilai-nilai ajaran Islam sebagai sumbernya (Direktorat Pemberdayaan Wakaf 2006). Sedangkan pada masa Kolonial Belanda setidaknya ditemukan 4 (empat) regulasi yang mengatur wakaf (Direktorat Pemberdayaan Wakaf 2006), yaitu:

1. Surat Edaran Sekretaris Governemen Pertama tanggal 31 Januari 1905, No. 435, tentang Toezicht op den bouw van Muhammadaansche bedehuizen. Surat edaran tersebut berisi ketentuan bahwa Pemerintah Kolonial Belanda tidak melarang praktik wakaf untuk kepentingan keagamaan.

2. Surat Edaran Sekretaris Governemen tanggal 4 Juni 1931 nomor 1361/A, tentang Toezicht van regeerin opMuhammadaansche bedehuizen, vrijdag diensten en wakafs. Surat tersebut berisi tentang mekanisme wakaf yang harus mendapatkan izin dari Bupati. Permohonan wakaf yang sudah mendapatkan izin Bupati, dimasukkkan dalam daftar yang kemudian diserahkan kepada Ketua Pengadilan Agama. Keseluruhan daftar permohonan wakaf tersebut, selanjutnya diserahkan kepada Asisten Wedana untuk 
ditindaklanjuti oleh Kantor Landrente.

3. Surat Edaran Sekretaris Governemen tanggal 24 Desember 1934 nomor 3088/A, tentang Toezicht van de regeerin opMuhammadaansche bedehuizen, vrijdag diensten en wakafs. Surat ini hanya mempertegas surat edaran sebelumnya, yaitu mengenai kewenangan Bupati dalam menyelesaikan sengketa tentang tanah wakaf.

4. Surat Edaran Sekretaris Governemen tanggal 27 Mei 1935 nomor 1273/A. Surat edaran ini berisi tentang tata cara perwakafan sebagai realisasi ketentuan Bijblad nomor $6169 / 1905$ yang menghendaki adanya registrasi dari tanah wakaf.

Hukum wakaf yang berkembang pada masa Kolonial Belanda terus berkembang di masa berikutnya. Pada masa Orde Lama, serangkaian peraturan perundangan mengenai wakaf diterbitkan, antara lain(Direktorat Pemberdayaan Wakaf 2006):

1. Petunjuk Departemen Agama Republi Indonesia tanggal 22 Desember 1953 tentang petunjuk-petunjuktentang wakaf.

2. Surat Edaran Nomor 5/D/1956 tanggal 8 Oktober 1956 Tentang Prosedur Wakaf Tanah.

3. Undang-Undang 5 Tahun 1960 tentang Pokok-Pokok Agraria.

Pada masa Orde Baru, perkembangan hukum wakaf ditandai dengan lahirnya peraturan teknis pelaksanaan wakaf di Indonesia. Adapun peraturan tersebut adalah sebagai berikut(Direktorat Pemberdayaan Wakaf 2006):

1. Peraturan pemerintah (PP) Nomor 28 Tahun 1977 tentang Perwakafan Tanah Milik. Peraturan ini merupakan aturan pelaksanaan dari Pasal 49 ayat (3) Undang-Undang No. 5 Tahun 1960 Tentang Pokok Agraria.

2. Kompilasi Hukum Islam (KHI)yang mengakomodasi adanya aset selain tanah untuk dijadikan wakaf. $\mathrm{KHI}$ sendiri merupakan salah satu aturan turunan Peraturan pemerintah (PP) Nomor 28 Tahun 1977 tentang Perwakafan Tanah Milik yang tertuang dalam Intruksi Presiden No. 1 Tahun 1991 (Ali 2012).Akomodasi ini nampak pada definisi wakaf menurut Kompilasi Hukum Islam (KHI) yang menjelaskan bahwa wakaf merupakan perbuatan hukum seseorang atau kelompok orang atau badan hukum yang memisahkan sebagian dari benda miliknya dan melembagakannya untuk selama-lamanya guna kepentingan ibadat atau kepentingan umum lainnya sesuai dengan ajaran Islam.

\section{E. Peraturan Perundangan Wakaf Uang di Indonesia}

\section{Jenis Harta Wakaf}

Peraturan perundangan wakaf uang di Indonesia mulai menunjukkan progresivitasnya, terutama saat menjadikan benda yang bergerak sebagai salah satu obyek harta wakaf. Persepsi sebagian publik di Indonesia telah menjadikan wakaf identik 
dengan tanah, seolah obyek harta wakaf hanyalah berupa harta yang tidak bergerak. Padahal apabila merujuk pada UU No. 41 Tahun 2004, maka akan ditemukan bahwa obyek harta wakaf tidak hanya berupa harta yang tidak bergerak, melainkan juga harta yang bergerak.

Sebagaimana terdapat dalam UU No. 41 Tahun 2004 Pasal 16 ayat 1, dinyatakan bahwa harta benda wakaf terdiri atas benda bergerak dan benda tidak bergerak. Benda tidak bergerak meliputi hak atas tanah sesuai dengan ketentuan peraturan perundangundangan yang berlaku baik yang sudah maupun yang belum terdaftar, bangunan atau bagian bangunan yang berdiri di atas tanah, tanaman dan benda lain yang berkaitan dengan tanah, hak milik atas satuan rumah susun sesuai dengan ketentuan peraturan perundang-undangan yang berlaku, dan benda tidak bergerak lain sesuai dengan ketentuan syariah dan peraturan perundang-undangan yang berlaku. Sedangkan benda bergerakterdiri atas uang, logam mulia, surat berharga, kendaraan, hak atas kekayaan intelektual, hak sewa dan benda bergerak lain sesuai dengan ketentuan syariah dan peraturan perundang-undangan yang berlaku.

Jenis harta benda wakaf dirinci kembali dalam Peraturan Pemerintah Nomor 42 Tahun 2006 Tentang Pelaksanaan UU No. 41 Tahun 2004 Tentang Wakaf. Dalam PP No 42 Tahun 2006 dijelaskan bahwa jenis harta benda wakaf meliputi benda tidak bergerak, benda bergerak selain uang, dan benda bergerak berupa uang. Adapun pembagian benda tidak bergerak sebagaimana dimaksud dalam Pasal 15 tersebut adalah sebagai berikut:

a. Hak atas tanah sesuai dengan ketentuan Peraturan Perundang-undangan baik yang sudah maupun yang belum terdaftar.

b. Bangunan atau bagian bangunan yang berdiri di atas tanah.

c. Tanaman dan benda lain yang berkaitan dengan tanah

d. Hak milik atas satuan rumah susun sesuai dengan ketentuan Peraturan Perundangundangan.

e. Benda tidak bergerak lain sesuai dengan ketentuan prinsip syariah dan Peraturan Perundang-undangan.

Lebih jauh, Pasal 19 memuat tentang benda bergerak selain uang. Dalam Pasal tersebut dijelaskan bahwa benda digolongkan sebagai benda bergerak karena sifatnya yang dapat berpindah atau dipindahkan atau karena ketetapan undang-undang. Benda bergerak terbagi dalam benda bergerak yang dapat dihabiskan dan yang tidak dapat dihabiskan karena pemakaian. Benda bergerak yang dapat dihabiskan karena pemakaian tidak dapat diwakafkan, kecuali air dan bahan bakar minyak yang persediaannya berkelanjutan. Benda bergerak yang tidak dapat dihabiskan karena pemakaian dapat diwakafkan dengan memperhatikan ketentuan prinsip syariah. Benda bergerak karena 
sifatnya yang dapat diwakafkan meliputi:

1. Kapal.

2. Pesawat terbang.

3. Kendaraan bermotor.

4. Mesin atau peralatan industri yang tidak tertancap pada bangunan.

5. Logam dan batu mulia.

6. Benda benda lainnya yang tergolong sebagai benda bergerak karena sifatnya dan memiliki manfaat jangka panjang.

Benda bergerak selain uang karena Peraturan Perundang-undangan yang dapat diwakafkan sepanjang tidak bertentangan dengan prinsip syariah adalah sebagai berikut:

a. Surat berharga yang berupa saham, surat utang negara, obligasi pada umumnya dan/atau surat berharga lainnya yang dapat dinilai dengan uang.

b. Hak Atas Kekayaan Intelektual yang berupa hak cipta, hak merk, hak paten, hak desain industri, hak rahasia dagang, hak sirkuit terpadu, hak perlindungan varietas tanaman, dan/atau hak lainnya.

c. Hak atas benda bergerak lainnya yang berupa 1) hak sewa, hak pakai dan hak pakai hasil atas benda bergerakserta, 2)perikatan, tuntutan atas jumlah uang yang dapat ditagih atas benda bergerak.

Wakaf uang yang dapat diwakafkan adalah mata uang rupiah. Apabila uang yang akan diwakafkan masih dalam mata uang asing, maka harus dikonversi terlebih dahulu ke dalam rupiah. Bahkan Surat berharga yang berupa saham, surat utang negara, obligasi pada umumnya dan/atau surat berharga lainnya dapat diwakafkan.Dengan diakomodirnya uang dan benda bergerak lainnya sebagai salah satu benda wakaf, maka UU No. 41 Tahun 2004 telah menunjukkan kemajuan yang fundamental.

Sebagai konsekuensi logis dari pengelompokan kategori benda wakaf tersebut, maka pengaturan mengenai tata cara pendaftaran harta benda wakaf dibedakan menjadi dua macam, yaitu:

a. Tata cara pendaftaran wakaf harta benda wakaf tidak bergerak berdasarkan Akta Ikrar Wakaf (AIW) atau APAIW setelah memenuhi persyaratan tertentu;

b. Tata cara pendaftaran wakaf uang melalui Lembaga Keuangan Syariah (LKS), yang atas nama Nazhir menerbitkan Sertifikat Wakaf Uang;

c. Tata cara pendaftaran wakaf benda bergerak selain uang melalui instansi yang berwenang sesuai dengan sifat benda bergerak tersebut. 


\section{Pembentukan LKS Penerima Wakaf Uang}

Kemajuan Hukum Wakaf dalam pengembangan wakaf uang juga nampak pada aspek kelembagaan wakaf uang. Wakif dapat mewakafkan benda bergerak berupa uang melalui Lembaga Keuangan Syariah yang ditunjuk oleh Menteri sebagai LKS Penerima Wakaf Uang (LKS-PWU). Dalam Peraturan Pemerintah Nomor 42 Tahun 2006, dijelaskan bahwa Lembaga Keuangan Syariah yang ditunjuk oleh Menteri sebagaimana dimaksud dalam Pasal 23 atas dasar saran dan pertimbangan dari Badan Wakaf Indonesia (BWI). Adapun tugas LKS-PWU adalah sebagai berikut:

a. Mengumumkan kepada publik atas keberadaannya sebagai LKS Penerima Wakaf Uang.

b. Menyediakan blangko Sertifikat Wakaf Uang.

c. Menerima secara tunai wakaf uang dari Wakif atas nama Nazhir.

d. Menempatkan uang wakaf ke dalam rekening titipan (wadi'ah) atas nama Nazhir yang ditunjuk Wakif.

e. Menerima pernyataan kehendak Wakif yang dituangkan secara tertulis dalam formulir pernyataan kehendak Wakif.

f. Menerbitkan Sertifikat Wakaf Uang serta menyerahkan sertifikat tersebut kepada Wakif dan menyerahkan tembusan sertifikat kepada Nazhir yang ditunjuk oleh Wakif.

g. Mendaftarkan wakaf uang kepada Menteri atas nama Nazhir.

\section{Badan Wakaf Indonesia Sebagai Regulator Wakaf}

UU No. 41 Tahun 2004 secara jelas telah memberikan kewenangan kepada BWI dalam tata kelola wakaf. Badan Wakaf Indonesia berperan sebagai regulator wakaf di Indonesia. Pada Bab VI, Pasal 47 disebutkan bahwa Badan Wakaf Indonesia dibentuk dalam rangka memajukan dan mengembangkan perwakafan nasional. Badan Wakaf Indonesia merupakan lembaga independen dalam melaksanakan tugasnya. Sebagaimana dijelaskan dalam Pasal 49 ayat 1, bahwa Badan Wakaf Indonesia mempunyai tugas dan wewenang sebagai berikut:

a. Melakukan pembinaan terhadap Nazhir dalam mengelola dan mengembangkan harta benda wakaf.

b. Melakukan pengelolaan dan pengembangan harta benda wakaf berskala nasional dan internasional.

c. Memberikan persetujuan dan/atau izin atas perubahan peruntukan dan status harta benda wakaf.

d. Memberhentikan dan mengganti Nazhir.

e. Memberikan persetujuan atas penukaran harta benda wakaf. 
f. Memberikan saran dan pertimbangan kepada Pemerintah dalam penyusunan kebijakan di bidang perwakafan.

\section{Pengelolaan dan Investasi Wakaf Uang}

Pengelolaan wakaf uang dilakukan oleh nazhir terdiri atasSetoran Wakaf Uang, Investasi Wakaf Uang serta Hasil Investasi Wakaf Uang. Pengelolaan tersebut ditujukan untuk optimalisasi perolehan keuntungan dan/atau pemberdayaan ekonomi ummat. Secara spesifik, pengelolaan wakaf uang diatur dalamPeraturan BWI No. 1 Tahun 2009 Tentang Pedoman Pengelolaan dan Pengembangan Harta Benda Wakaf Bergerak Berupa Uang, adapun ketentuannya adalah sebagai berikut:

a. Pengelolaan Wakaf Uang oleh Nazhir meliputi Setoran Wakaf Uang, Investasi Wakaf Uang serta Hasil Investasi Wakaf Uang.

b. Nazhir wajib membedakan pengelolaan antara Wakaf Uang dalam Jangka Waktu tertentu dengan Wakaf Uang untuk waktu selamanya.

c. Dalam hal pengelolaan Wakaf Uang dalam jangka waktu tertentu, Nazhir wajib memastikan terpenuhinya pembayaran atas Wakaf Uang dalam jangka waktu terbatas yang jatuh waktu.

d. Dalam hal pengelolaan dan pengembangan Wakaf Uang di Bank Syariah tidak termasuk dalam program lembaga penjamin simpanan, Nazhir tetap wajib menjamin tidak berkurangnya dana setoran Wakaf Uang dimaksud.

e. Pengelolaan dan pengembangan Wakaf Uang atas setoran Wakaf Uang dan investasi Wakaf Uang oleh Nazhir wajib ditujukan untuk optimalisasi perolehan keuntungan dan/atau pemberdayaan ekonomi ummat.

f. Pengelolaan dan pengembangan Wakaf Uang atas hasil investasi Wakaf Uang oleh Nazhir wajib ditujukan untuk pemberdayaan ekonomi ummat dan/atau kegiatankegiatan sosial keagamaan.

g. Hasil bersih atas pengelolaan dan pengembangan harta benda Wakaf Uang yang menjadi dasar penghitungan besarnya imbalan bagi Nazhir adalah Hasil Investasi Wakaf Uang setelah dikurangi dengan biaya-biaya yang terkait dengan pengelolaan dan pengembangan Wakaf Uang.

h. Biaya-biaya yang terkait dengan pengelolaan dan pengembangan Wakaf Uang sebagaimana dimaksud pada point (7), antara lain biaya penerimaan setoran Wakaf Uang, pendaftaran Wakaf Uang kepada Menteri dan laporan rekapitulasi Wakaf Uang, biaya asuransi terkait investasi Wakaf Uang serta biaya administrasi Nazhir.

i. Besarnya imbalan bagi Nazhir dari hasil bersih investasi Wakaf Uang, ditetapkan paling banyak sebagai berikut : 
1. $10 \%$ (sepuluh perseratus), apabila besarnya investasi Wakaf Uang paling kurang mencapai $90 \%$ (sembilan puluh perseratus) dibanding setoran Wakaf Uang;

2. $9 \%$ (sembilan perseratus), apabila besarnya investasi Wakaf Uang paling kurang mencapai $70 \%$ (tujuh puluh perseratus) dibanding setoran Wakaf Uang;

3. $8 \%$ (delapan perseratus), apabila besarnya investasi Wakaf Uang paling kurang mencapai 50\% (lima puluh perseratus) dibanding setoran Wakaf Uang;

4. $5 \%$ (lima perseratus), apabila besarnya investasi Wakaf Uang dibawah 50\% (lima puluh perseratus) dibanding setoran Wakaf Uang.

Sedangkan berkaitan dengan investasi wakaf uang, dalam Pasal 10 Peraturan BWI No. 1 Tahun 2009, disebutkan bahwa investasi wakaf uang ditujukan untuk proyekproyek produktif bagi kemaslahatan umat melalui investasi secara langsung dan tidak langsung.Investasi secara langsung merupakan investasi pada proyek-proyek yang dikelola oleh Nazhir. Adapun investasi secara tidak langsung adalah investasi melalui lembaga yang memenuhi kriteria kelayakan kelembagaan dan menguntungkan. Secara teknis, investasi wakaf uang dapat dilakukan melalui deposito di Bank Syariah dengan ekspektasi bagi hasil yang paling menguntungkan.Investasi Wakaf Uang secara langsung pada proyek-proyek yang dikelola oleh Nazhir dapat dilakukan apabila proyek tersebut memenuhi persyaratan:

a. Usaha proyek dijalankan sesuai dengan syariah Islam.

b. Tingkat kelayakan proyek memenuhi syarat kelayakan proyek sesuai prinsip $5 \mathrm{C}$ (Character, Condition, Capital, Capacity, Collateral), dan 3 P (People, Purpose, Payment).

c. Sumber pengembalian dapat dihitung berdasarkan studi kelayakan.

\section{E. Progresivitas Hukum Wakaf dalam Pengembangan Wakaf Uang}

Progresivitas hukum wakaf dalam pengembangan wakaf uang di Indonesia sudah cukup baik. Hal ini ditandai dengan terbitnya peraturan-peraturan sebagai respon atas wacana implementasi wakaf uang. Sementara sejarah perkembangan hukum wakaf di Indonesia sebelum masa reformasi, menunjukkan bahwa peraturan perundang-undangan yang secara eksplisit mengatur wakaf hanyalah Peraturan Pemerintah No. 28 Tahun 1977 Tentang Wakaf Tanah.

Peraturan tentang wakaf uang nampak progresivitasnya pada masa reformasi. salah satu peraturan tersebut antara lain Fatwa Majels Ulama Indonesia (MUI) tentang Wakaf Uang. Fatwa yang diterbitkan pada 11 Mei 2002 tersebut merupakan respon 
atas surat Direktur Pengembangan Zakat dan Wakaf Departemen Agama No. Dt.1.III/5/ BA.03.2/2772/2002 yang berisi tentang permohonan fatwa tentang wakaf uang(Direktorat Pemberdayaan Wakaf 2006). Permohonan fatwa ini bertujuan agar wakaf menjadi instrumen keuangan Islam yang pelaksanaannya lebih fleksibel dan dapat memberikan dampak secara fundamental kepada umat. Ketentuan dalam fatwa tersebut antara lain:

a. Wakaf Uang adalah wakaf yang dilakukan seseorang, kelompok orang, lembaga atau abdan hukum dalam bentuk uang tunai.

b. Termasuk dalam pengertian uang adalah surat-surat berharga.

c. Wakaf uang hukumnya jawaz (boleh).

d. Wakaf uang hanya untuk hal-hal yang diperbolehkan secara syar'i.

Selain fatwa MUI, pasca reformasi juga lahir UU No. 41 Tahun 2004 tentang Wakaf. Penyusunan Undang-undang ini atas usulan pembentukan Badan Wakaf Indonesia (BWI) berdasarkan Surat Meteri Agama No. MA/320/2002. Usulan pembentukan BWI sendiri juga bagian dari repon positif atas bergulirnya wacana wakaf uang, yaitu perlunya lembaga khusus yang melakukan tata kelola wakaf secara nasional di Indonesia. Permintaan Menteri Agama tersebut melahirkan usulan dari Sekretariat Negara agar Menteri Agama menyiapkan izin prakarsa pengajuan rancangan Undang-undang Wakaf kepada DPR RI (Direktorat Pemberdayaan Wakaf 2006). Sebagai pelaksana UU No. 41 Tahun 2004, maka diterbitkanlah Peraturan Pemerintah No. 42 Tahun 2006. Undang-undang Wakaf dan Peraturan Pemerintah sebagai pelaksana Undang-undang merupakan cerminan perkembangan praktik wakaf uang yang ditandai dengan hal-hal yang baru(Hamzani 2014), antara lain:

a. Wakaf tidak terbatas pada benda tidak bergerak seperti tanah dan bangunan, namun juga berupa benda bergerak.

b. Peruntukan wakaf tidak hanya terbatas pada bidang ibadah dan sosial, melainkan juga pada kemajuan kesejahteraan ekonomi.

c. UU dan PP akan mendorong terhadap upaya pengelolaaan aset wakaf secara produktif yang menuntut profesionalisme nazhir.

Progresivitas hukum wakaf dalam pengembangan wakaf uang juga nampak pada beberapa peraturan yang secara khusus mengatur tentang wakaf uang. Misalnya adalah Peraturan BWI No. 1 Tahun 2009 Tentang Pedoman Pengelolaan dan Pengembangan Harta Benda Wakaf Bergerak Berupa Uang.Dalam peraturan tersebut diatur mengenai hal-hal teknis penyelenggaraan wakaf uang. Dengan demikian penyelenggaraan wakaf uang tidak lagi bersifat normatif-teoritik. Lebih jauh penyelenggaraan wakaf uang sudah disertai dengan petunjuk teknis yang jelas pedomannya, misalnya dalam pasal 3 dijelaskan mengenai ketentuan Penerimaan Wakaf Uang sebagai berikut:

a. Penerimaan Wakaf Uang dari Wakif dapat dilakukan melalui Wakaf Uang dalam jangka waktu tertentu dan Wakaf Uang untuk waktu selamanya. 
b. Wakif yang menyetorkan Wakaf Uang paling kurang Rp1.000.000,00 (satu juta rupiah) akan memperoleh Sertikat Wakaf Uang.

c. Penerimaan Wakaf Uang dalam jangka waktu tertentu paling kurang untuk jangka waktu 5 (lima) tahun dan paling kurang sejumlah Rp10.000.000,00 (sepuluh juta rupiah).

d. Penerimaan Wakaf Uang dimana Wakif menentukan sendiri Mauquf alaih ditetapkan paling kurang sejumlah Rp1.000.000.000,00 (satu milyar rupiah).

Peraturan BWI juga mengatur tentang pedoman pengelolaan dan pengembangan wakaf uang. Ini menunjukkan bahwa peraturan perundangan wakaf tidak hanya memberikan ruang dan legitimasi terhadap penyelenggaraan wakaf uang, namun juga mengatur aspek teknis yang lebih instrumentatif. Mengenai pengelolaan dan pengembangan wakaf uang diatur dalam Pasal 7, Peraturan Badan Wakaf Indonesia Nomor 4 Tahun 2010 Tentang Pedoman Pengelolaan dan Pengembangan Harta Benda Wakaf, adapun pedomannya adalah sebagai berikut:

1. Pengelolaan dan pengembangan wakaf uang hanya dapat dilakukan melalui investasi pada produk-produk LKS dan/atau instrumen keuangan syariah.

2. Dalam hal LKS-PWU menerima wakaf uang untuk jangka waktu tertentu, Nazhir hanya dapat melakukan pengelolaan dan pengembangan di LKS-PWU dimaksud.

3. Pengelolaan dan pengembangan wakaf uang pada bank syariah yang telah dijamin oleh lembaga penjamin simpanan.

4. Pengelolaan dan pengembangan wakaf uang dapat dilakukan dalam bentuk investasi di luar produk-produk LKS atas persetujuan dari BWI.

5. Persetujuan sebagaimana dimaksud pada point (4) diberikan setelah terlebih dahulu BWI melakukan kajian atas kelayakan investasi dimaksud.

6. Pengelolaan dan pengembangan wakaf uang dalam bentuk investasi selain pada bank syariah harus diasuransikan pada asuransi syariah.

7. Sebaran investasi harta dalam bentuk wakaf uang (portofolio wakaf uang) dapat dilakukan dengan ketentuan $60 \%$ (enam puluh perseratus) investasi dalam instrumen LKS dan $40 \%$ (empat puluh perseratus) di luar LKS.

Progresivitas hukum wakaf sudah cukup baik dalam pengembangan wakaf uang di Indonesia. Kondisi ini harus disertai dengan kesiapan seluruh pemangku kepentingan(stakeholder) yang terkait dengan tata kelola wakaf. Lebih jauh, masyarakat muslim harus mendapatkan transformasi dan edukasi hukum wakaf yang cukup, sehingga partisipasi dalam wakaf uang lebih optimal. 


\section{Daftar Pustaka}

Ali, Mohaamd Daud. 2012. Sistem Ekonomi Islam, Zakat Dan Wakaf. Jakarta: UI Press.

Anshori, Abdul Ghofur. 2005. Hukum Dan Praktik Perwakafan Di Indonesia. Yogyakarta: Pilar Media.

Badan Wakaf Indonesia. 2008a. "Database Dan Potensi Wakaf." 2008. http://www.bwi.or.id/ index.php/ar/component/content/article/80-database-dan-potensi-wakaf.html.

- - . 2008b. "Menengok Potensi Wakaf Di Indonesia." 2008. http://www.bwi.or.id/index. php/publikasi/berita-mainmenu-109/266-menengok-potensi-wakaf-di-indonesia.

Direktorat Pemberdayaan Wakaf. 2006. Perkembangan Pengelolaan Wakaf Di Indonesia. Jakarta: Departemen Agama RI.

Hamzani, Achamd Irwan. 2014. "Kontekstualisasi Hukum Islam Di Indonesia: Studi Terhadap Hukum Wakaf." Jurnal MMH 43 (3): 340-47.

Muljawan, Dadang, Raditya Sukmana, and Diana Yumanita. 2016. Wakaf: Pengaturan Dan Tata Kelola Yang Efeketif. 1st ed. Jakarta: Departemen Ekonomi dan Keuangan Syariah - Bank Indonesia.

Zuhaili, Wahbah. 1985. Al-Fiqhu Al-Islami Wa 'Adillatuhu. Damaskus: Dar al-Fikr alMu'ashir. 